\title{
Effects of $\mathrm{NaCl}$ on Growth and Cesium Absorption in Quinoa (Chenopodium quinoa Willd.)
}

\author{
Katsunori Isobe (i) - Emi Nakajima • Nozomi Morita • \\ Shihomi Kawakura • Masao Higo
}

Received: 5 June 2018 / Accepted: 11 February 2019/Published online: 21 February 2019

(C) The Author(s) 2019

\begin{abstract}
In this study, we clarified the effects of $\mathrm{NaCl}$ application on the growth and Cs absorption in quinoa (Chenopodium quinoa Willd.). Pot experiments using Wagner pots (1/5000a) were conducted in an experimental field at Nihon University during 2014, 2015, and 2016 , using quinoa variety CICA-127. Growth of quinoa and $\mathrm{Cs}$ absorption by quinoa were promoted by the application of $\mathrm{NaCl}$. The $\mathrm{Cs}$ content of aboveground parts of plants was also increased by the application of $\mathrm{NaCl}$; however, the differences in Cs content among plots were not significant. Thus, the reason for the increase in Cs absorption was the promotion of biomass by the application of $\mathrm{NaCl}$. The exchangeable $\mathrm{K}$ content in the soil and the growth of quinoa were increased by the application of $\mathrm{KCl}$. Therefore, increasing the exchangeable $\mathrm{K}$ content in soil by the application of $\mathrm{KCl}$ has contributed to the increased accumulation of $\mathrm{K}$ and the decreased accumulation of $\mathrm{Cs}$ in the aboveground parts of plants. Thus, the lower exchangeable $\mathrm{K}$ content in soil led to a lower plant $\mathrm{K}$ content and a greater absorption of $\mathrm{Cs}$ by quinoa.
\end{abstract}

Keywords Cesium $\cdot$ Exchangeable potassium $\cdot \mathrm{NaCl}$. Quinoa (Chenopodium quinoa Willd.)

K. Isobe $(\bowtie) \cdot$ E. Nakajima $\cdot$ N. Morita $\cdot$ S. Kawakura $\cdot$ M. Higo

College of Bioresource Sciences, Nihon University, Fujisawa, Kanagawa 252-0880, Japan

e-mail: isobe64@brs.nihon-u.ac.jp

\section{Introduction}

Many plant species are very sensitive to soil salinity, and growth is often inhibited under high salinity conditions (Tuteja 2007). However, the growth of some plant species is promoted under high salinity conditions; these plant species are generally known as halophytes (Tuteja 2007; Flower and Colmer 2008; Orlovsky et al. 2016). Quinoa (Chenopodium quinoa Willd.) is known to be a halophyte, with high salinity tolerance (Jacobsen et al. 2003; Koyro et al. 2008; Adolf et al. 2012). Several studies have shown quinoa to be highly tolerant to salinity at germination and various other growth stages (Isobe et al. 2014; Saleem et al. 2017). Many halophytes absorb $\mathrm{K}$ ions $\left(\mathrm{K}^{+}\right)$from soil in order to grow under high salinity conditions (Tuteja 2007). K and Cs are group I alkali metals, with similar chemical properties (White and Broadley 2000; Nishioka et al. 2011). The influx of these cations to root cells is mediated by the same molecular mechanism (White and Broadley 2000). Thus, we consider that under high salinity conditions, quinoa plants increase absorption of $\mathrm{Cs}$ ions $\left(\mathrm{Cs}^{+}\right)$, but not absorb them instead of $\mathrm{K}^{+}$from soil. Quinoa plants have been identified to have with the highest Cs absorption capacity (Broadley et al. 1999).

A large amount of radiocesium $\left({ }^{134} \mathrm{Cs}\right.$ and $\left.{ }^{137} \mathrm{Cs}\right)$ was released into the environment as a consequence of the accident at Fukushima Daiichi Nuclear Power Plant that occurred on March 11, 2011 (Chino et al. 2011; Fujii et al. 2014). The released radiocesium was deposited on land and sea surfaces. In agricultural fields, there has 
been a focus on reducing the translocation of radiocesium from soil to the edible parts of crops (Miyahara 2014; Watanabe 2014; Sato 2014). Phytoremediation is a useful plant-based cleanup technique for decontaminating soils; it can decontaminate large areas of agricultural land at a low cost (Broadley et al. 1999; Dushenkov et al. 1999; Hayakawa and Kurihara 2002; Sato 2014; Ogata et al. 2015; Kubo et al. 2016; Kang et al. 2017; Kubo et al. 2017). As quinoa has a very high Cs absorption capacity (Broadley et al. 1999) and grows well under high sodium chloride $(\mathrm{NaCl})$ conditions (Jacobsen et al. 2001; Wilson et al. 2002; Isobe et al. 2014), we hypothesized that when quinoa growth is promoted under high $\mathrm{NaCl}$ conditions, its Cs absorption capacity would also increase. In this study, thus, we aimed to clarify the effects of $\mathrm{NaCl}$ application on the growth of quinoa and Cs absorption by quinoa.

\section{Materials and Methods}

Pot experiments were conducted in an experimental field at Nihon University (Fujisawa City, Kanagawa, Japan) during 2014, 2015, and 2016, using quinoa variety CICA-127. Wagner pots (1/5000a; diameter about $16 \mathrm{~cm}$, high about $25 \mathrm{~cm}$ ) were used in all experiments.

\section{Experiment 1: Effects of $\mathrm{NaCl}$ on Quinoa Growth}

In pots containing a mixture of $3.2 \mathrm{~kg}$ field soil (Andosol) and $0 \mathrm{~g}, 8 \mathrm{~g}, 16 \mathrm{~g}, 24 \mathrm{~g}, 32 \mathrm{~g}$, or $48 \mathrm{~g}$ of $\mathrm{NaCl}$ (Wako Pure Chemical Industries, Tokyo, Japan), 20 quinoa seeds per pot were sown on August 18, 2014. In this experiment, $\mathrm{N}, \mathrm{P}$, and $\mathrm{K}$ fertilizers were not applied to the pots. The seedlings were thinned to three plants per pot at the second or third leaf stage. All pots (10 pots per plot) were placed randomly and independently in an unheated glass (roof) and net (side) house from sowing to maturity, and weeds, diseases, and insects were controlled as necessary during the cultivation period. On November 6, 2014, the aboveground parts of plants (stems and leaves) of ten pots per plot were cut at the soil surface, and about $20 \mathrm{~g}$ of soil in these pots was sampled randomly.

The dry weight of aboveground parts of plants from five pots per plot was determined after the samples had been oven dried at $80^{\circ} \mathrm{C}$ for $48 \mathrm{~h}$. The fresh weight, $\mathrm{Na}$ content, and $\mathrm{K}$ content of aboveground parts of plants as well as leaf area were measured using the aboveground parts of plants from another five pots. The fresh weight of aboveground parts of plants was measured with an electric balance. Leaf areas were measured with an area meter (LI-310, LI-COR Inc., Lincoln, NE, USA). The fresh aboveground parts of plants were ground using a pestle and mortar. The $\mathrm{Na}$ and $\mathrm{K}$ contents of the aboveground parts of plants were determined with an $\mathrm{Na}$ ion meter (SO30, HORIBA, Tokyo, Japan) and a $\mathrm{K}$ ion meter (SO22, HORIBA, Tokyo, Japan), respectively. The $\mathrm{Na}$ and $\mathrm{K}$ absorptions of the aboveground parts of plants were calculated by multiplying the fresh weights of the aboveground parts of plants by the $\mathrm{Na}$ and $\mathrm{K}$ content values.

The soil samples were air-dried to measure the following chemical properties: $\mathrm{pH}\left(\mathrm{H}_{2} \mathrm{O}\right)$, electrical conductivity (EC), and soil available $\mathrm{Na}$ content. $\mathrm{pH}$ and EC were measured using the glass electrode method and the 1:5 water extraction method, respectively. The soil available $\mathrm{Na}$ was extracted from the soil samples using a soil-to-solution ratio of 1:5 in water and shaking with a shaker (MMS-310, EYELA, Tokyo, Japan) for $1 \mathrm{~h}$. The soil available $\mathrm{Na}$ content was determined by atomic absorption spectrophotometry (Z-8200, Hitachi HighTech Science, Tokyo, Japan).

All values were expressed as averages and standard errors. The data were analyzed statistically, and significant differences at 5\% level among the plots were determined by Tukey multiple means test using Kaleida Graph ver.4.0 software.

\section{Experiment 2: Effects of $N$ and $P$ Fertilizer and $\mathrm{NaCl}$ on Cs Absorption and Growth of Quinoa}

Twenty quinoa seeds per pot were sown on August 18, 2015, in pots containing $3.2 \mathrm{~kg}$ of field soil and $0.10 \mathrm{~g}$ of $\mathrm{CsCl}$ (Wako Pure Chemical Industries, Tokyo, Japan). $\mathrm{CsCl}$ was added to the top $5 \mathrm{~cm}$ of the soil in all plots (contain control). In this experiment, there were four treatments: $\mathrm{NaCl}$, fertilizer, $\mathrm{NaCl}+$ fertilizer, and a control with no added $\mathrm{NaCl}$ or fertilizer, and prepared ten pots in each plot. In the $\mathrm{NaCl}$ plot, $24.0 \mathrm{~g}$ of $\mathrm{NaCl}$ was applied to each pot. In the fertilizer plot, $0.2 \mathrm{~g}$ of each $\mathrm{N}$ and $\mathrm{P}_{2} \mathrm{O}_{5}$, as ammonium sulfate (TORAY Ind. Inc., Tokyo, Japan) and superphosphate (Katakura \& Co-op Agri Corporation), respectively, was applied to each pot; this fertilizer amount was shown by pre- 
experiment to result in the optimum growth of quinoa in this type of pot. In the $\mathrm{NaCl}+$ fertilizer plot, $\mathrm{NaCl}$ and $\mathrm{N}$ and $\mathrm{P}_{2} \mathrm{O}_{5}$ fertilizer were applied to each pot. The seedlings were thinned to three plants per pot at the second or third leaf stage. In this experiment, the $\mathrm{NaCl}(24.0 \mathrm{~g})$ and fertilizer $\left(0.2 \mathrm{~g}\right.$ of each $\mathrm{N}$ and $\left.\mathrm{P}_{2} \mathrm{O}_{5}\right)$ were equally mixed with $3.2 \mathrm{~kg}$ of soil.

On October 21 and November 10, 2015, the aboveground parts of plants from five pots in each plot were cut at the soil surface. The fresh weight of aboveground parts of plants, the leaf area, and the dry weights of aboveground parts of plants was measured by the same method of experiment 1 . The dry aboveground parts of plants were ground to a powder using a blender. To measure Cs concentration, $0.5 \mathrm{~g}$ ground material was digested in $20.0 \mathrm{~mL} \mathrm{HClO}_{4}$ (Kanto Chemical Co., Inc., Tokyo, Japan) for $3 \mathrm{~h}$ at $100{ }^{\circ} \mathrm{C}$ using an acid digestion system, and Cs content was determined by atomic absorption spectrophotometry (Z-8200 Hitachi High-Tech Science, Tokyo, Japan). The Cs absorption of aboveground parts of plants was measured by multiplying the dry weight of the aboveground parts of plants by the Cs content.

At the start (August 18) of this experiment, the top 5$\mathrm{cm}$ surface soil from five pots was sampled. The soil samples were air-dried to measure the following chemical properties: $\mathrm{pH}\left(\mathrm{H}_{2} \mathrm{O}\right), \mathrm{EC}$, total Cs content, and soil available $\mathrm{Na}$ content. The $\mathrm{pH}, \mathrm{EC}$, and available $\mathrm{Na}$ content were measured by the same method of experiment 1 . To measure soil total Cs concentration, $2.0 \mathrm{~g}$ airdried soil sample was digested in $20.0 \mathrm{~mL} \mathrm{HClO}_{4}$ for $3 \mathrm{~h}$ at $100{ }^{\circ} \mathrm{C}$. The total $\mathrm{Cs}$ content and available $\mathrm{Na}$ content were determined by atomic absorption spectrophotometry (Z-8200 Hitachi High-Tech Science, Tokyo, Japan).

All values were expressed as averages and standard errors. The data were analyzed statistically, and significant differences among the plots were determined by two-way ANOVA using Kaleida Graph ver.4.0 software.

\section{Experiment 3: Effect of $\mathrm{KCl}$ on Cs Absorption and Growth of Quinoa Under High $\mathrm{NaCl}$ Conditions}

In this experiment, $3.2 \mathrm{~kg}$ field soil, $24.0 \mathrm{~g}$ of $\mathrm{NaCl}$, $0.10 \mathrm{~g}$ of $\mathrm{CsCl}$, and $0.2 \mathrm{~g}$ each of $\mathrm{N}$ and $\mathrm{P}_{2} \mathrm{O}_{5}$, as ammonium sulfate and superphosphate, respectively, were applied to all pots. The exchangeable $\mathrm{K}$ of the soil was $11.83 \mathrm{mg}$ per $100 \mathrm{~g}$; the treatments comprised $0.0 \mathrm{~g}$,
$0.8 \mathrm{~g}$, or $3.0 \mathrm{~g}$ of $\mathrm{KCl}$. In each plot, 20 quinoa seeds per pot were sown on April 30, 2016. The seedlings were thinned to three plants per pot at the second or third leaf stage.

On June 28 and July 18, 2016, the aboveground parts of plants of 10 pots per each plot were cut at the soil surface, and the soil sampled. The fresh weight of aboveground parts of plants, leaf area, $\mathrm{K}$ content, and $\mathrm{K}$ absorption (K content $\times$ fresh weight) of aboveground parts of plants from five pots per plot were measured by the same method of experiment 1 . The dry weight, Cs content, and Cs absorption of aboveground parts of plants from five pots per plot were determined by the same method of experiment 2 .

At the start (April 30) of this experiment, the top 5$\mathrm{cm}$ surface soil from five pots was sampled. The soil samples were air-dried to measure the following chemical properties: $\mathrm{pH}\left(\mathrm{H}_{2} \mathrm{O}\right), \mathrm{EC}$, available $\mathrm{K}$ content, and total Cs content. The $\mathrm{pH}, \mathrm{EC}$, and total Cs content were measured by the same method of experiment 1 or 2 . The available $\mathrm{K}$ content was extracted from the soil samples using a soil-to-solution ratio of 1:2 in $0.1 \mathrm{M}$ ammonium acetate and shaking for $10 \mathrm{~min}$. The available $\mathrm{K}$ content was determined by atomic absorption spectrophotometry (Z-8200).

All values were expressed as averages and standard errors. The data were analyzed statistically, and significant differences at 5\% level among the plots were determined by Tukey multiple means test using Kaleida Graph ver.4.0 software.

\section{Results}

\subsection{Experiment 1}

\subsubsection{Soil Chemistry}

Soil $\mathrm{pH}$ decreased with increasing $\mathrm{NaCl}$ application rates. There was also an increase in $\mathrm{EC}$ and $\mathrm{Na}$ content with increasing $\mathrm{NaCl}$ application rates. These differences were significant at the 5\% level (Table 1).

\subsubsection{Quinoa Growth}

There were significant differences at the $5 \%$ level in the leaf area, fresh weight of aboveground parts of plants, and dry weight of aboveground parts of plants between plots. There was an increase in leaf area and fresh 
Table 1 Effects of $\mathrm{NaCl}$ application on the soil chemistry

\begin{tabular}{llll}
\hline Plots & $\mathrm{pH}$ & $\mathrm{EC}\left(\mathrm{dS} \mathrm{m}^{-1}\right)$ & $\mathrm{Na}\left({\left.\mathrm{mg} 100 \mathrm{~g}^{-1}\right)}^{-}\right.$ \\
\hline $0 \mathrm{~g}$ & $6.0 \pm 0.02 \mathrm{a}$ & $0.07 \pm 0.00 \mathrm{~d}$ & $0.8 \pm 0.0 \mathrm{~d}$ \\
$8 \mathrm{~g}$ & $5.2 \pm 0.02 \mathrm{~b}$ & $0.97 \pm 0.13 \mathrm{~cd}$ & $73.7 \pm 3.8 \mathrm{~cd}$ \\
$16 \mathrm{~g}$ & $5.0 \pm 0.02 \mathrm{bc}$ & $2.73 \pm 0.02 \mathrm{bc}$ & $301.7 \pm 31.0 \mathrm{bc}$ \\
$24 \mathrm{~g}$ & $5.0 \pm 0.00 \mathrm{bc}$ & $2.78 \pm 0.16 \mathrm{bc}$ & $354.3 \pm 18.5 \mathrm{~b}$ \\
$32 \mathrm{~g}$ & $5.0 \pm 0.02 \mathrm{bc}$ & $4.06 \pm 0.53 \mathrm{~b}$ & $507.5 \pm 76.3 \mathrm{~b}$ \\
$48 \mathrm{~g}$ & $4.8 \pm 0.02 \mathrm{c}$ & $7.01 \pm 0.77 \mathrm{a}$ & $919.2 \pm 111.9 \mathrm{a}$ \\
\hline
\end{tabular}

Average \pm standard error. Values followed by different letters are significantly different at $P=0.05$ by the Tukey test

weight of aboveground parts of plants with increasing $\mathrm{NaCl}$ application rates up to $32 \mathrm{~g}$ per pot. However, the leaf area and fresh weight of aboveground parts of plant of the 48-g plot were significantly lower than those of the 32-g plot. The dry weight of aboveground parts of plant increased with increasing $\mathrm{NaCl}$ application rates up to $16 \mathrm{~g}$ per pot. However, $\mathrm{NaCl}$ application rates from $16 \mathrm{~g}$ per pot to $48 \mathrm{~g}$ per pot resulted in a decrease in dry weight of aboveground parts of plants. However, there were no significant differences in the leaf area, fresh weight of aboveground parts of plants, and dry weight of aboveground parts of plants between the plots with applications of $16 \mathrm{~g}, 24 \mathrm{~g}$, and $32 \mathrm{~g}$ of $\mathrm{NaCl}$ (Table 2, Fig. 1).

\section{2 $\mathrm{Na}$ and $\mathrm{K}$ Absorption}

$\mathrm{Na}$ content and $\mathrm{Na}$ absorption of the aboveground parts of plants increased with increasing $\mathrm{NaCl}$ application rates, with significant differences at the 5\% level between plots. There were no significant differences in the $\mathrm{K}$ content of the aboveground parts of plants between plots. There were significant differences at the $5 \%$ level in the $\mathrm{K}$ absorption of aboveground parts of plant between plots, with an increase in $\mathrm{K}$ absorption of the aboveground parts of plants with increasing $\mathrm{NaCl}$ application rates up to $32 \mathrm{~g}$ per pot; the $\mathrm{K}$ absorption of the aboveground parts of plants decreased when the $\mathrm{NaCl}$ application rate was increased from $32 \mathrm{~g}$ per pot to $48 \mathrm{~g}$ per pot. However, there were no significant differences in the $\mathrm{K}$ absorption of the aboveground parts of plants among the 16-g, 24-g, 32-g, and 48-g plots (Table 3).

\subsection{Experiment 2}

\subsubsection{Soil Chemistry}

There were significant differences at $1 \%$ or $0.1 \%$ level in soil $\mathrm{pH}$, electric conductivity, and available $\mathrm{Na}$ content between $\mathrm{NaCl}$ and fertilizer treatments. The soil $\mathrm{pH}$ of the $\mathrm{NaCl}$ plot was lower than that of the other plots. The $\mathrm{NaCl}$ plots also resulted in a higher EC and available $\mathrm{Na}$ content than the other plots. However, there was no significant difference in the total Cs content between all treatments (Table 4).

\subsubsection{Quinoa Growth}

On October 21, there were significant differences in the leaf area, fresh weight of aboveground parts of plants, and dry weight of aboveground parts of plants between $\mathrm{NaCl}$ treatments. The leaf area, fresh weight, and dry weight of $\mathrm{NaCl}$ and $\mathrm{NaCl}+$ fertilizer plots were higher than those of control and fertilizer plots. However, on October 21, there were no significant differences between the fertilizer and $\mathrm{NaCl}$ in fertilize treatments. On November 10, there were significant differences in leaf area, fresh weight, and dry weight between $\mathrm{NaCl}$ and fertilizer treatments. The leaf area, fresh weight, and dry weight of $\mathrm{NaCl}$,

Table 2 Effects of $\mathrm{NaCl}$ application on the quinoa growth

\begin{tabular}{llll}
\hline Plots & Leaf area $\left(\mathrm{cm}^{2}\right.$ pot $\left.^{-1}\right)$ & $\begin{array}{l}\text { Fresh weight of aboveground } \\
\text { parts of plants }\left(\mathrm{g} \mathrm{pot}^{-1}\right)\end{array}$ & $\begin{array}{l}\text { Dry weight of aboveground } \\
\left.\text { parts of plants }(\mathrm{g} \mathrm{pot})^{-1}\right)\end{array}$ \\
\hline $0 \mathrm{~g}$ & $125.4 \pm 12.5 \mathrm{c}$ & $10.3 \pm 1.0 \mathrm{~d}$ & $2.23 \pm 1.91 \mathrm{~d}$ \\
$8 \mathrm{~g}$ & $191.2 \pm 14.6 \mathrm{bc}$ & $16.1 \pm 1.2 \mathrm{c}$ & $3.20 \pm 2.91 \mathrm{bc}$ \\
$16 \mathrm{~g}$ & $229.9 \pm 20.3 \mathrm{ab}$ & $21.3 \pm 1.9 \mathrm{ab}$ & $4.21 \pm 2.45 \mathrm{a}$ \\
$24 \mathrm{~g}$ & $251.0 \pm 19.4 \mathrm{ab}$ & $21.3 \pm 1.8 \mathrm{ab}$ & $3.63 \pm 3.14 \mathrm{ab}$ \\
$32 \mathrm{~g}$ & $300.2 \pm 24.7 \mathrm{a}$ & $22.7 \pm 1.9 \mathrm{a}$ & $3.79 \pm 3.91 \mathrm{ab}$ \\
$48 \mathrm{~g}$ & $220.0 \pm 19.1 \mathrm{~b}$ & $17.2 \pm 1.4 \mathrm{bc}$ & $2.54 \pm 2.19 \mathrm{~cd}$ \\
\hline
\end{tabular}

Average \pm standard error. Values followed by different letters are significantly different at $P=0.05$ by the Tukey test 
Fig. 1 Effects of $\mathrm{NaCl}$ application on the quinoa growth

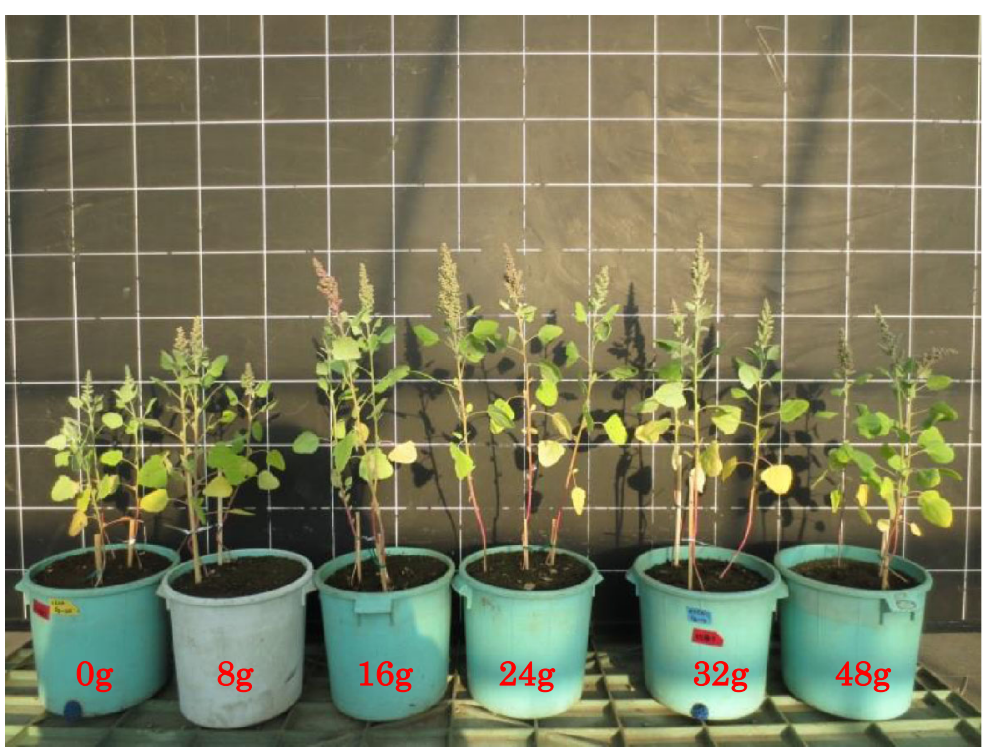

fertilizer, and $\mathrm{NaCl}+$ fertilizer plots were higher than those of control (Table 5).

\subsubsection{Cs Absorption}

On October 21 and November 10, there was no significant difference in Cs content of the aboveground parts of plants between $\mathrm{NaCl}$ treatments. However, there was a significant difference at 5\% level in Cs absorption of aboveground parts of plants between $\mathrm{NaCl}$ treatments. But, differences between fertilizer treatments detected only for Cs content of aboveground parts of plants on October 21. On October 21 and November 10, there was no significant difference in Cs content and absorption of aboveground parts of plants between the $\mathrm{NaCl}$ in fertilize treatments. The highest $\mathrm{Cs}$ absorption of the aboveground parts of plants was for the $\mathrm{NaCl}+$ fertilizer plot; those were $1.10 \mathrm{mg}$ per pot and $4.44 \mathrm{mg}$ per pot, on October 21 and November 10, respectively (Table 6).

\subsection{Experiment 3}

\subsubsection{Soil Chemistry}

Significant differences at the $5 \%$ level were observed in soil $\mathrm{pH}, \mathrm{EC}$, and $\mathrm{K}$ content among plots. The soil $\mathrm{pH}$ of the $0.0 \mathrm{-g}$ plot was lower than that of the other plots. The highest $\mathrm{EC}$ and available $\mathrm{K}$ content among plots were in the 3.0 -g plot. The $\mathrm{K}$ content was $11.8 \mathrm{mg}$ per $100 \mathrm{~g}$, $19.7 \mathrm{mg}$ per $100 \mathrm{~g}$, and $26.7 \mathrm{mg}$ per $100 \mathrm{~g}$ in the $0.0-\mathrm{g}$, $0.8 \mathrm{-g}$, and $3.0 \mathrm{-g}$ plots, respectively. There were no significant differences in total Cs content between plots (Table 7).

Table 3 Effects of $\mathrm{NaCl}$ application on the $\mathrm{K}$ and $\mathrm{Na}$ absorption

\begin{tabular}{lllll}
\hline Plots & $\begin{array}{l}\text { Na content of aboveground } \\
\text { parts of plant }(\mathrm{ppm})\end{array}$ & $\begin{array}{l}\text { Na absorption of aboveground } \\
\text { parts of plant }\left(\mathrm{mg} \mathrm{pot}^{-1}\right)\end{array}$ & $\begin{array}{l}\text { K content of aboveground } \\
\text { parts of plant }(\%)\end{array}$ & $\begin{array}{l}\text { K absorption of aboveground } \\
\text { parts of plant }\left(\mathrm{mg} \mathrm{pot}^{-1}\right)\end{array}$ \\
\hline $0 \mathrm{~g}$ & $170 \pm 16.1 \mathrm{c}$ & $1.76 \pm 0.16 \mathrm{c}$ & $1.03 \pm 0.14 \mathrm{a}$ & $106.4 \pm 9.2 \mathrm{c}$ \\
$8 \mathrm{~g}$ & $290 \pm 19.9 \mathrm{c}$ & $4.56 \pm 0.32 \mathrm{c}$ & $0.94 \pm 0.06 \mathrm{a}$ & $152.1 \pm 13.7 \mathrm{bc}$ \\
$16 \mathrm{~g}$ & $340 \pm 27.3 \mathrm{bc}$ & $7.19 \pm 0.66 \mathrm{bc}$ & $1.00 \pm 0.10 \mathrm{a}$ & $212.3 \pm 21.4 \mathrm{ab}$ \\
$24 \mathrm{~g}$ & $620 \pm 53.8 \mathrm{ab}$ & $13.12 \pm 1.39 \mathrm{ab}$ & $1.06 \pm 0.03 \mathrm{a}$ & $226.5 \pm 14.3 \mathrm{a}$ \\
$32 \mathrm{~g}$ & $640 \pm 66.0 \mathrm{ab}$ & $14.23 \pm 0.99 \mathrm{ab}$ & $1.05 \pm 0.15 \mathrm{a}$ & $237.5 \pm 21.9 \mathrm{a}$ \\
$48 \mathrm{~g}$ & $926 \pm 89.2 \mathrm{a}$ & $15.98 \pm 1.23 \mathrm{a}$ & $1.06 \pm 0.12 \mathrm{a}$ & $182.0 \pm 18.8 \mathrm{ab}$ \\
\hline
\end{tabular}

Average \pm standard error. Values followed by different letters are significantly different at $P=0.05$ by the Tukey test 
Table 4 Effects of $\mathrm{N}$ and $\mathrm{P}$ fertilizer and $\mathrm{NaCl}$ application on the soil chemical

\begin{tabular}{lllll}
\hline Plots & $\mathrm{pH}$ & $\mathrm{EC}\left(\mathrm{dS} \mathrm{m}^{-1}\right)$ & Available Na $\left({\left.\mathrm{mg} 100 \mathrm{~g}^{-1}\right)}\right.$ & Total Cs $\left(\mathrm{mg}^{\left.100 \mathrm{~g}^{-1}\right)}\right.$ \\
\hline Control & $5.4 \pm 0.02$ & $0.07 \pm 0.00$ & $2.3 \pm 0.1$ & $9.63 \pm 4.88$ \\
$\mathrm{NaCl}$ & $4.6 \pm 0.02$ & $4.34 \pm 0.26$ & $498.3 \pm 20.2$ & $7.33 \pm 0.08$ \\
Fertilizer & $5.3 \pm 0.06$ & $0.08 \pm 0.01$ & $1.3 \pm 0.1$ & $6.38 \pm 0.08$ \\
$\mathrm{NaCl}+$ fertilizer & $5.2 \pm 0.06$ & $2.01 \pm 0.14$ & $228.0 \pm 11.6$ & $7.83 \pm 0.08$ \\
$\mathrm{ANOVA}$ & & & & $\mathrm{ns}$ \\
$\mathrm{NaCl}$ & $* *$ & $* * *$ & $* * *$ & $\mathrm{~ns}$ \\
$\mathrm{Fertilizer}$ & $* *$ & $* *$ & $* * *$ & $\mathrm{~ns}$ \\
$\mathrm{NaCl} \times$ fertilizer & $* *$ & $* *$ & & \\
\hline
\end{tabular}

Average \pm standard error

$n s$ not statistically significant at $P=0.05$

***, **Statistically significant at $P=0.001$ and 0.01 , respectively

\subsubsection{Quinoa Growth}

There were significant differences at the 5\% level in leaf area, fresh weight of aboveground parts of plants, and dry weight of aboveground parts of plants among plots. On June 28 and July 18, the highest leaf area and fresh weight of aboveground parts of plants were in the $3.0-\mathrm{g}$ plot. The highest dry weight of aboveground parts of plants was in the 0.8 -g plot and the 3.0 -g plot on June 28 and July 18 , respectively (Table 8 ).

\subsubsection{K and Cs Absorption}

$\mathrm{K}$ content and $\mathrm{K}$ absorption of the aboveground parts of plants increased with increasing $\mathrm{KCl}$ application rates, with significant differences at the $5 \%$ level between plots. However, Cs content and Cs absorption of the aboveground parts of plants decreased with increasing $\mathrm{KCl}$ application rates, with significant differences at the $5 \%$ level between 0.0 -g plot and the other plots (Table 9).

\section{Discussion}

\subsection{Effects of $\mathrm{NaCl}$ on the Growth of Quinoa}

Salinity is the most important abiotic stress that adversely affects crop productivity. A number of studies have indicated that quinoa is regarded as having a high

Table 5 Effects of $\mathrm{N}$ and $\mathrm{P}$ fertilizer and $\mathrm{NaCl}$ application on the quinoa growth

\begin{tabular}{|c|c|c|c|c|c|c|}
\hline \multirow[t]{2}{*}{ Plots } & \multicolumn{2}{|c|}{ Leaf area $\left(\mathrm{cm}^{2} \operatorname{pot}^{-1}\right)$} & \multicolumn{2}{|c|}{$\begin{array}{l}\text { Fresh weight of aboveground } \\
\text { parts of plants }\left(\mathrm{g} \mathrm{pot}^{-1}\right)\end{array}$} & \multicolumn{2}{|c|}{$\begin{array}{l}\text { Dry weight of aboveground } \\
\text { parts of plants }\left(\mathrm{g} \mathrm{pot}^{-1}\right)\end{array}$} \\
\hline & Oct. 21 & Nov. 10 & Oct. 21 & Nov. 10 & Oct. 21 & Nov. 10 \\
\hline Control & $183.7 \pm 7.4$ & $134.1 \pm 13.2$ & $9.9 \pm 0.4$ & $10.9 \pm 1.1$ & $1.45 \pm 0.23$ & $1.72 \pm 0.26$ \\
\hline $\mathrm{NaCl}$ & $281.3 \pm 14.3$ & $218.5 \pm 21.2$ & $16.9 \pm 0.9$ & $20.6 \pm 0.7$ & $2.01 \pm 0.17$ & $3.34 \pm 0.11$ \\
\hline Fertilizer & $168.1 \pm 10.3$ & $241.1 \pm 32.8$ & $8.7 \pm 0.5$ & $14.1 \pm 1.6$ & $1.10 \pm 0.07$ & $2.21 \pm 0.36$ \\
\hline $\mathrm{NaCl}+$ fertilizer & $241.0 \pm 37.1$ & $521.6 \pm 13.9$ & $13.9 \pm 1.0$ & $38.0 \pm 2.8$ & $1.64 \pm 0.27$ & $5.54 \pm 0.78$ \\
\hline \multicolumn{7}{|l|}{ ANOVA } \\
\hline $\mathrm{NaCl}$ & $* *$ & $* * *$ & $* *$ & $* * *$ & $*$ & $* *$ \\
\hline Fertilizer & ns & $* * *$ & ns & $* *$ & ns & $*$ \\
\hline $\mathrm{NaCl} \times$ fertilizer & ns & $* *$ & ns & $* *$ & ns & ns \\
\hline
\end{tabular}

Average \pm standard error

$n s$ not statistically significant at $P=0.05$

$* * *, * *$, Statistically significant at $P=0.001,0.01$, and 0.05 , respectively 
Table 6 Effects of $\mathrm{N}$ and $\mathrm{P}$ fertilizer and $\mathrm{NaCl}$ application on the $\mathrm{Cs}$ absorption

\begin{tabular}{|c|c|c|c|c|}
\hline \multirow[t]{2}{*}{ Plots } & \multicolumn{2}{|c|}{ Cs content of aboveground parts of plant ( $\left.\mathrm{mg} \mathrm{g}^{-1}\right)$} & \multicolumn{2}{|c|}{ Cs absorption of aboveground parts of plant (mg pot $\left.{ }^{-1}\right)$} \\
\hline & Oct. 21 & Nov. 10 & Oct. 21 & Nov. 10 \\
\hline Control & $0.20 \pm 0.01$ & $0.21 \pm 0.08$ & $0.23 \pm 0.03$ & $0.29 \pm 0.11$ \\
\hline $\mathrm{NaCl}$ & $0.49 \pm 0.08$ & $0.41 \pm 0.14$ & $1.04 \pm 0.24$ & $1.37 \pm 0.46$ \\
\hline Fertilizer & $0.70 \pm 0.22$ & $0.23 \pm 0.05$ & $0.83 \pm 0.28$ & $0.48 \pm 0.12$ \\
\hline $\mathrm{NaCl}+$ fertilizer & $0.56 \pm 0.06$ & $0.68 \pm 0.20$ & $1.10 \pm 0.20$ & $4.44 \pm 1.78$ \\
\hline \multicolumn{5}{|l|}{ ANOVA } \\
\hline $\mathrm{NaCl}$ & ns & ns & $*$ & * \\
\hline Fertilizer & $*$ & ns & ns & ns \\
\hline $\mathrm{NaCl} \times$ fertilizer & ns & ns & ns & $\mathrm{ns}$ \\
\hline
\end{tabular}

Average \pm standard error

$n s$ not statistically significant at $P=0.05$

*Statistically significant at $P=0.05$

tolerance to salinity. For example, Morales et al. (2011) clarified that quinoa plants exhibited a greater tolerance to salt stress than the model plant, Thellungiella halophila. Jacobsen et al. (2001) evaluated the level of salt tolerance in quinoa on application of saline water. Plants were treated with nine levels of salinity, with EC from $<1$ to $40 \mathrm{dS} \mathrm{m}^{-1}$. In this experiment, the highest seed yield was obtained at an EC of $15 \mathrm{dS} \mathrm{m}^{-1}$. Quinoa salinity sensitivity studies have also been conducted on the cultivar Andean Hybrid (Wilson et al. 2002). In this experiment, the quinoa plants exhibited an increase in growth at $11 \mathrm{dS} \mathrm{m}^{-1}$, compared with that at $3 \mathrm{dS} \mathrm{m}^{-1}$. In our experiment 1 , the highest leaf area was 32-g plot, and the highest dry weight was 16-g plot. EC of both plots ranged from 2.73 to $4.06 \mathrm{dS} \mathrm{m}^{-1}$ (Table 1). From these results, the optimum EC for quinoa growth was 2.78 to $4.06 \mathrm{dS} \mathrm{m}^{-1}$ in this condition. Jacobsen et al. (2001), Wilson et al. (2002), and we measured EC at the start of experiments. However, our result was different from those of other experiments (Jacobsen et al. 2001; Wilson et al. 2002). We think that one of the reasons of difference of optimum EC for quinoa growth was the difference of the growth environments, for example, pot size. However, the growth of quinoa was also promoted by the application of $\mathrm{NaCl}$ (Table 2, Fig. 1). The results of these experiments indicated that quinoa is a facultative halophyte and that the growth of quinoa is promoted under saline conditions. Moreover, in our experiment 2, the growth of quinoa was also promoted by the application of $\mathrm{NaCl}$ (Table 5), with the growth in the $\mathrm{NaCl}+$ fertilizer plot being greater than that of the $\mathrm{NaCl}$ plot (Table 5). This result suggested a difference in the mechanism of growth promotion by $\mathrm{NaCl}$ and that by $\mathrm{N}$ and $\mathrm{P}_{2} \mathrm{O}_{5}$ fertilizer.

The presence of salt in the soil reduces the ability of a plant to take up water, which leads to a reduction in growth (Tuteja 2007). This is referred to as the osmotic or water-deficit effect of salinity. One of reasons for quinoa's high adaptability to soil salinity is better metabolic control, compared with that of the non-halophytic species (Ruffino et al. 2010). Quinoa maintains cell turgor and limits transpiration under saline conditions, avoiding physiological damage from drought and thus potential death. Moreover, ionic and osmotic relations in quinoa have been studied by exposing plants to six salinity levels (Hariadi et al. 2011). In this experiment,

Table 7 Effects of $\mathrm{KCl}$ application on the soil chemical

\begin{tabular}{lllll}
\hline Plots & $\mathrm{pH}$ & $\mathrm{EC}\left(\mathrm{dS} \mathrm{m}^{-1}\right)$ & Available K $\left(\mathrm{mg} 100 \mathrm{~g}^{-1}\right)$ & Total Cs $\left(\mathrm{mg}^{\left.100 \mathrm{~g}^{-1}\right)}\right.$ \\
\hline $0.0 \mathrm{~g}$ & $5.2 \pm 0.03 \mathrm{~b}$ & $3.53 \pm 0.19 \mathrm{~b}$ & $11.8 \pm 0.4 \mathrm{c}$ & $7.08 \pm 0.16 \mathrm{a}$ \\
$0.8 \mathrm{~g}$ & $5.3 \pm 0.02 \mathrm{a}$ & $3.62 \pm 0.29 \mathrm{ab}$ & $19.7 \pm 1.1 \mathrm{~b}$ & $8.75 \pm 0.12 \mathrm{a}$ \\
$3.0 \mathrm{~g}$ & $5.3 \pm 0.05 \mathrm{a}$ & $3.98 \pm 0.16 \mathrm{a}$ & $26.7 \pm 1.0 \mathrm{a}$ & $9.33 \pm 0.18 \mathrm{a}$ \\
\hline
\end{tabular}

Average \pm standard error. Values followed by different letters are significantly different at $P=0.05$ by the Tukey HSD test 
Table 8 Effects of $\mathrm{KCl}$ application on the quinoa growth

\begin{tabular}{|c|c|c|c|c|c|c|}
\hline \multirow[t]{2}{*}{ Plots } & \multicolumn{2}{|c|}{ Leaf area $\left(\mathrm{cm}^{2} \operatorname{pot}^{-1}\right)$} & \multicolumn{2}{|c|}{$\begin{array}{l}\text { Fresh weight of aboveground } \\
\text { parts of plants }\left(\mathrm{g} \mathrm{pot}^{-1}\right)\end{array}$} & \multicolumn{2}{|c|}{$\begin{array}{l}\text { Dry weight of aboveground } \\
\text { parts of plants }\left(\mathrm{g} \mathrm{pot}^{-1}\right)\end{array}$} \\
\hline & Jun. 28 & Jul. 18 & Jun. 28 & Jul. 18 & Jun. 28 & Jul. 18 \\
\hline $0.0 \mathrm{~g}$ & $583.3 \pm 24.0 \mathrm{c}$ & $334.0 \pm 31.9 \mathrm{~b}$ & $42.9 \pm 2.6 b$ & $42.4 \pm 2.6 b$ & $6.8 \pm 0.4 \mathrm{~b}$ & $9.3 \pm 0.5 \mathrm{~b}$ \\
\hline $0.8 \mathrm{~g}$ & $779.1 \pm 47.2 \mathrm{~b}$ & $335.5 \pm 34.0 \mathrm{~b}$ & $65.6 \pm 3.4 \mathrm{a}$ & $56.5 \pm 2.3 \mathrm{a}$ & $10.9 \pm 0.7 \mathrm{a}$ & $13.9 \pm 0.5 \mathrm{a}$ \\
\hline $3.0 \mathrm{~g}$ & $957.7 \pm 14.1 \mathrm{a}$ & $624.7 \pm 68.1 \mathrm{a}$ & $65.8 \pm 2.4 \mathrm{a}$ & $67.1 \pm 3.6 \mathrm{a}$ & $10.2 \pm 0.5 \mathrm{a}$ & $14.8 \pm 0.8 \mathrm{a}$ \\
\hline
\end{tabular}

Average \pm standard error. Values followed by different letters are significantly different at $P=0.05$ by the Tukey HSD test

up to $80 \%$ of the osmotic adjustment in the leaves was achieved by means of the accumulation of inorganic ions $\left(\mathrm{Na}^{+}, \mathrm{K}^{+}\right.$, and $\left.\mathrm{Cl}^{-}\right)$under high $\mathrm{NaCl}$ levels, while the contribution of organic osmolytes was very limited. Additionally, the $\mathrm{K}^{+}$level in shoots progressively increased with the increased salinity in leaves; this is interpreted as evidence for the important role of $\mathrm{K}^{+}$in leaf osmotic adjustment under high saline conditions. However, in our experiment 1 , the $\mathrm{Na}^{+}$content of the aboveground parts of plants was greater under conditions with high $\mathrm{NaCl}$ application, whereas the $\mathrm{K}^{+}$content of the aboveground parts of plants did not increase (Table 3). This result was different from that reported by Hariadi et al. (2011). In our experiment 1, the application of $\mathrm{NaCl}$ did not increase the $\mathrm{K}$ content of aboveground parts of plants (Table 3). We think that available $\mathrm{K}$ in soil might be limited for quinoa growth, because no $\mathrm{K}$ fertilizer was added in this experiment. This may be one of the reasons why the results of our result were different from previous work (Hariadi et al. 2011). A further study is needed to clarify this point.

\subsection{Effects of $\mathrm{NaCl}$ and $\mathrm{KCl}$ on $\mathrm{Cs}$ Absorption}

In our experiment 2, the Cs absorption of aboveground parts of plants was increased by the application of $\mathrm{NaCl}$. Additionally, there were significant differences in the Cs absorption of aboveground parts of plants between $\mathrm{NaCl}$ treatments (Table 6). The reason for the increase in Cs absorption was the promotion of growth by the application of $\mathrm{NaCl}$ (Table 5). We think that Cs content of aboveground parts of plants was apparently increased by the $\mathrm{NaCl}$ treatment, even if might not have a significant difference. This means that Cs uptake might be accelerated by the $\mathrm{NaCl}$ treatment, possibly due to the decrease in available $\mathrm{K}$ content in soil in the $\mathrm{NaCl}$ treatment, because $\mathrm{Cs}$ is absorbed by plant roots competitively with $\mathrm{K}$. We think that available $\mathrm{K}$ content in soil might be lower in the $\mathrm{NaCl}$ treatment due to the bigger biomass (Table 5). Tamaoki et al. (2016) reported a positive relationship between total ${ }^{137} \mathrm{Cs}$ absorption and plant biomass, and the contribution rate of plant biomass to the total ${ }^{137} \mathrm{Cs}$ uptake by plants was $91.3 \%$. These results were almost the same as the results of our experiment (Tables 5 and 6) and indicate that a higher biomass is important for Cs absorption. In this experiment, the Cs content of aboveground parts of plants was also increased by the application of $\mathrm{NaCl}$. However, there were no significant differences in $\mathrm{Cs}$ content between $\mathrm{NaCl}$ treatments (Table 6). Thus, the effects of $\mathrm{NaCl}$ application on the Cs content of quinoa remain to be elucidated.

Table 9 Effects of $\mathrm{KCl}$ application on the $\mathrm{K}$ and $\mathrm{Cs}$ absorption

\begin{tabular}{|c|c|c|c|c|c|c|c|c|}
\hline \multirow[t]{2}{*}{ Plots } & \multicolumn{2}{|c|}{$\begin{array}{l}\text { K content of aboveground } \\
\text { parts of plant }(\%)\end{array}$} & \multicolumn{2}{|c|}{$\begin{array}{l}\text { K absorption of aboveground } \\
\text { parts of plants }\left(\mathrm{mg} \mathrm{pot}^{-1}\right)\end{array}$} & \multicolumn{2}{|c|}{$\begin{array}{l}\text { Cs content of aboveground } \\
\text { parts of plants }\left(\mathrm{mg} \mathrm{g}^{-1}\right)\end{array}$} & \multicolumn{2}{|c|}{$\begin{array}{l}\text { Cs absorption of aboveground } \\
\text { parts of plants }\left(\mathrm{mg} \mathrm{pot}^{-1}\right)\end{array}$} \\
\hline & Jun. 28 & Jul. 18 & Jun. 28 & Jul. 18 & Jun. 28 & Jul. 18 & Jun. 28 & Jul. 18 \\
\hline $0.0 \mathrm{~g}$ & $0.71 \pm 0.03 \mathrm{c}$ & $0.80 \pm 0.10 \mathrm{~b}$ & $304.7 \pm 18.5 \mathrm{c}$ & $337.4 \pm 20.6 \mathrm{c}$ & $0.82 \pm 0.07 \mathrm{a}$ & $0.78 \pm 0.04 \mathrm{a}$ & $5.56 \pm 0.47 \mathrm{a}$ & $7.21 \pm 0.34 \mathrm{a}$ \\
\hline $0.8 \mathrm{~g}$ & $0.96 \pm 0.01 \mathrm{~b}$ & $1.09 \pm 0.06 \mathrm{ab}$ & $627.5 \pm 32.6 \mathrm{~b}$ & $617.4 \pm 25.2 \mathrm{~b}$ & $0.17 \pm 0.02 \mathrm{~b}$ & $0.13 \pm 0.02 \mathrm{~b}$ & $1.85 \pm 0.22 \mathrm{~b}$ & $1.74 \pm 0.21 \mathrm{~b}$ \\
\hline $3.0 \mathrm{~g}$ & $1.13 \pm 0.03 \mathrm{a}$ & $1.27 \pm 0.03 \mathrm{a}$ & $745.4 \pm 27.1 \mathrm{a}$ & $850.3 \pm 45.0 \mathrm{a}$ & $0.06 \pm 0.03 \mathrm{~b}$ & $0.06 \pm 0.01 \mathrm{~b}$ & $0.60 \pm 0.27 \mathrm{~b}$ & $0.86 \pm 0.13 \mathrm{~b}$ \\
\hline
\end{tabular}

Average \pm standard error. Values followed by different letters are significantly different at $P=0.05$ by the Tukey HSD test 
In our experiment 3 , the exchangeable $\mathrm{K}$ content in soil and the growth of quinoa were increased by the application of $\mathrm{KCl}$ (Tables 7 and 8). Therefore, increasing the exchangeable $\mathrm{K}$ content in soil by applying $\mathrm{KCl}$ has contributed to the increased accumulation of $\mathrm{K}$ and the decreased accumulation of $\mathrm{Cs}$ in the aboveground parts of plants of quinoa (Table 9). Ii et al. (2015) reported that radiocesium in rice was reduced depending on the exchangeable $\mathrm{K}$ content of the soil, which plateaus at around $20 \mathrm{mg} \mathrm{K}_{2} \mathrm{O}$ per $100 \mathrm{~g}$ dry soil. In our experiment 3 , the exchangeable $\mathrm{K}$ content in the $0.8 \mathrm{~g}$ and 3.0-g plots was $19.7 \mathrm{mg}\left(\mathrm{K}_{2} \mathrm{O} 23.7 \mathrm{mg}\right)$ and $26.7 \mathrm{mg}\left(\mathrm{K}_{2} \mathrm{O} 32.2 \mathrm{mg}\right)$ per $100 \mathrm{~g}$ dry soil, respectively. From this result, the absorption of Cs in the 0.8 -g and 3.0-g plots was inhibited by the increase in exchangeable $\mathrm{K}$ content. Physiological studies have demonstrated that $\mathrm{K}^{+}$and $\mathrm{Cs}^{+}$compete for influx in excised roots, suggesting that the influx of these cations to root cells is mediated by the same molecular mechanism (White and Broadley 2000; Adams et al. 2005). From this, we suggest that when the $K$ content of plants is increased, the Cs content is decreased. In our experiment 3, the Cs content of aboveground parts of plants decreased with the increasing application of $\mathrm{KCl}$, resulting in a greater $\mathrm{K}$ content (Table 9).

\section{Conclusion}

In this study, we clarified the effects of $\mathrm{NaCl}$ application on the growth and Cs absorption activity of quinoa (C. quinoa Willd.). The growth and Cs absorption of quinoa, and the Cs content of quinoa aboveground parts of plants, were promoted by the application of $\mathrm{NaCl}$. The reason for the increase in Cs absorption was the promotion of biomass by the application of $\mathrm{NaCl}$. The exchangeable $\mathrm{K}$ content in the soil and the growth of quinoa were increased by the application of $\mathrm{KCl}$. Therefore, increasing the exchangeable $\mathrm{K}$ content in the soil by the application of $\mathrm{KCl}$ contributed to the increased accumulation of $\mathrm{K}$ and the decreased accumulation of $\mathrm{Cs}$ in quinoa aboveground parts of plants. Thus, the lower exchangeable $\mathrm{K}$ content in soil led to a lower plant $\mathrm{K}$ content, resulting in greater $\mathrm{Cs}$ absorption by quinoa.

Open Access This article is distributed under the terms of the Creative Commons Attribution 4.0 International License (http:// creativecommons.org/licenses/by/4.0/), which permits unrestricted use, distribution, and reproduction in any medium, provided you give appropriate credit to the original author(s) and the source, provide a link to the Creative Commons license, and indicate if changes were made.
Publisher's Note Springer Nature remains neutral with regard to jurisdictional claims in published maps and institutional affiliations.

\section{References}

Adams, E., Chaban, V., Khandelia, H., \& Shin, R. (2005). Selective chemical bioding enhances cesium tolerance in plants through inhibition of cesium uptake. Scientific Reports, 5, 1-10.

Adolf, V. I., Shabala, S., Andersen, M. N., Razzaghi, F., \& Jacobsen, S.-E. (2012). Varietal differences of quinoa's tolerance to saline conditions. Plant and Soil, 357, 177-129.

Broadley, M. R., Willey, N. J., \& Mead, A. (1999). A method to assess taxonomic variation in shoot caesium concentration among flowering plants. Environmental Pollution, 106, 341349.

Chino, M., Nakayama, H., Nagai, H., Terada, H., Katata, G., \& Yamazaki, H. (2011). Preliminary estimation of release amounts of 131I and 137Cs accidentally discharged from the Fukushima Daiichi nuclear power plant into the atmosphere. Journal of Nuclear Science and Technology, 48, 1129-1134.

Dushenkov, S., MIkheev, A., Prokhnevsky, A., Ruchko, M., \& Sorochinsky, B. (1999). Phytoremediation of radiocesiumcontaminated soil in the vicinity of Chernobyl, Ukraine. Environmental Science \& Technology, 33, 469-475.

Flower, T. J., \& Colmer, T. D. (2008). Salinity tolerance in halophytes. The New Phytologist, 179, 945-963.

Fujii, K., Ikeda, S., Akama, A., Komatsu, M., Takahashi, M., \& Kaneko, S. (2014). Vertical migration of radiocesium and clay mineral composition in five forest soils contaminated by the Fukushiuma nuclear accident. Soil Science \& Plant Nutrition, 60, 751-764.

Hariadi, Y., Marandon, K., Tian, Y., Jacobsen, S.-E., \& Shabala, S. (2011). Ionic and osmotic relations in quinoa (Chenopodium quinoa Willd.) plants grown at various salinity levels. Journal of Experimental Botany, 62, 185-193.

Hayakawa, T., \& Kurihara, H. (2002). Trial for phytoremediation on the heavy metal pollution. Journal of Environment and Biotechnology, 2, 103-115.

Ii, I., Tanoi, K., Uno, Y., Nobori, T., Hirose, A., Kobayashi, N., Nihei, N., Ogawa, T., Tao, Y., Kanno, M., Nishiwaki, J., \& Mizoguchi, M. (2015). Radioactive caesium concentration of lowland Rice grown in the decontaminated paddy fields in Iitate-Vallage in Fukushima. Radioisotopes, 64, 299-310.

Isobe, K., Ogisima, E., Sato, R., Sugiyama, H., Higo, M., \& Torigoe, Y. (2014). Varietal and specific differences in salinity tolerance of quinoa (Chenopodium quinoa Willd.) for germination and initial growth. Jpn.J. Crop Science, 83, 914.

Jacobsen, S.-E., Quispe, H., \& Mujica, A. (2001). Quinoa: an alternative crop for saline soils in the Andes. In: Scientists and Farmer-Partners in Research for the 21st Century. CIP Progam Report 1999-2000. pp 403-408.

Jacobsen, S.-E., Mujica, A., \& Jensen, C. R. (2003). The resistance of quinoa (Chenopodium quinoa Willd.) to adverse abiotic factor. Food Reviews International, 19, 99-109. 
Kang, D.-J., Ishii, Y., Tazoe, H., Isobe, K., Higo, M., Hosoda, M., Yamada, M., \& Tokonami, S. (2017). Remediation of radiocesium-137 affected soil using Napiergrass under different planting density and cutting frequency regimes. Water, Air, and Soil Pollution, 228, 268-277.

Koyro, H.-W., Eisa, S. S., \& Lieth, H. (2008). Salt tolerance of Chenopodium quinoa Willd., grains of the Andes: influence of salinity on biomass production, yield, composition of reserves in the seeds, water and solute relations. Mangroves and Halophytes: Restoration and Utilisation, 43, 133-145.

Kubo, K., Fujimura, S., Kobayashi, H., Ota, T., \& Shinano, T. (2016). Decreasing radioactive cesium in lodged buckwheat grain after harvest. Plant Production Science, 19, 91-95.

Kubo, K., Fujimura, S., Kobayashi, H., Ota, T., \& Shinano, T. (2017). Effect of soil exchangeable potassium content on cesium absorption and partitioning in buckwheat grown in a radioactive cesium-contaminated field. Plant Production Science, 20, 396-405 (削除?m).

Miyahara, S. (2014). Surface soil scraping by agricultural tractors for farm land decontamination. Japanese Journal Soil Science and Plant Nutrition, 85, 125-128.

Morales, A. J., Baigain, P., Garver, Z., Maughan, P. J., \& Udall, J. A. (2011). Physiological responses of Chenopodium quinoa to salt stress. International Journal of Plant Physiology and Biochemistry, 3, 219-232.

Nishioka, H., Momose, T., Inoue, D., Fujiwara, K., Kitajima, T., Ohno, S., Tanaka, M., \& Suziki, T. (2011). Surface structures induced by alkali metal (K, Cs) adsorption on Si (111) —clusters observed for adsorbate coverages close to the saturation coverage- Journal of Surface Science Society of Japan, 32, 302-307.

Ogata, N., Fujita, T., \& Kato, M. (2015). Phytoremediation of radioactive cesium contaminated soil by cultivation of Amaranthus spp. Jpn.J. Crop Science, 84, 9-16.
Orlovsky, N., Japakova, U., Zhang, H., \& Volis, S. (2016). Effect of salinity on seed germination, growth and ion content in dimorphic seeds of Salicornia europaea L. (Chenopodiaceae). Plant Diversity, 38, 183-189.

Ruffino, A. M. C., Rosa, M., Hilal, M., Gonzalez, J. A., \& Prado, F. E. (2010). The role of cotyledon metabolism in the establishment of quinoa (Chenopodium quinoa) seedling growing under salinity. Plant and Soil, 326, 213-224.

Saleem, M. A., Basra, S. M. A., Afzal, I., ur-Reman, H., Iqbal, S., Saddiq, M. S., \& Naz, S. (2017). Exploring the potential of quinoa accessions for salt tolerance in soilless culture. International Journal of Agriculture and Biology, 19, 233240.

Sato, M. (2014). Verification of radiocesium removal by phytoremediation. Japanese Journal Soil Science and Plant Nutrition, 85, 136-137.

Tamaoki, M., Yabe, T., Furukawa, J., Watanabe, M., Ikeda, K., Yasutani, I., \& Nishizawa, T. (2016). Comparison of potentials of higher plants for phytoremediation of radioactive cesium from contaminated soil. Environmental Control in Biology, 54, 65-69.

Tuteja, N. (2007). Mechanisms of high salinity tolerance in plants. Methods in Enzymology, 428, 419-438.

Watanabe, Y. (2014). Burying radioactive cesium-contaminated soil by ploughing. Japanese Journal Soil Science and Plant Nutrition, 85, 129-131.

White, P.J., \& Broadley, M. R. (2000). Mechanisms of caesium uptake by plants. New Phytologist, 147, 241-256.

Wilson, C., Read, J. J., \& Abo-Kassem, E. (2002). Effect of mixed-salt salinity on growth and ion relations of a quinoa and wheat variety. Journal of Plant Nutrition, 25, 26892704. 